\title{
Lack of Ser267Phe variant of sodium taurocholate cotransporting polypeptide among Moroccans regardless of hepatitis $B$ virus infection status
}

\author{
Sayeh Ezzikouri ${ }^{*}$, Hajar Chihab ${ }^{1,2}$, Abdellah Elhabazi $^{2}$, Lahcen Wakrim ${ }^{3}$ and Soumaya Benjelloun ${ }^{1}$
}

\begin{abstract}
Background: The sodium taurocholate co-transporting polypeptide, encoded by SLC10A1, was identified as a functional receptor for hepatitis B virus (HBV). The objective of this study was to determine if there was an association of the Ser267Phe variant (rs2296651) with HBV infection status in Moroccan patients.

Methods: Using a TaqMan 5' allelic discrimination assay, the Ser267Phe variant was genotyped in 286 chronic hepatitis B patients, 135 individuals with spontaneous clearance from HBV infection and 109 healthy controls negative for hepatitis $B$ serological markers.
\end{abstract}

Results: In this cohort, we detected only wild-type genotype (S267S) in all groups. This polymorphism was not associated with the HBV infection status in Moroccan patients.

Conclusions: The S267F variant is absent among Moroccans regardless of chronic HBV infection status.

Keywords: Hepatitis B virus, Functional receptor, NTCP, Polymorphism

\section{Background}

Chronic hepatitis B (CHB) affects about 248 million people worldwide and can lead to liver cirrhosis, liver failure and hepatocellular carcinoma, especially in many Asian and African countries $[1,2]$. Whereas around $90 \%$ of the HBV-infected adults develop acute infection followed by spontaneous viral clearance, $5-10 \%$ of infected individuals are not able to clear the virus and develop chronic infection [3, 4]. Morocco is a country of intermediate endemicity of hepatitis B virus (HBV) and diverse modes of transmission including vertical, intra-familial, sexual or parenteral have been reported [5]. Several studies have highlighted that host genetic factors could influence the course of the disease [6, 7]. Recently, Yan and colleagues identified sodium taurocholate cotransporting polypeptide (NTCP) as a functional receptor of HBV [8]. NTCP is a member of the solute carrier family 10 (SLC10), the major bile acid uptake system in human hepatocytes, and localized to the basolateral hepatocyte membrane [9]. Silencing the NTCP expression in primary Tupaia hepatocytes, HepaRG or primary human hepatocytes diminished HBV infectivity [8]. A genetic polymorphism (S267F, c.800G > A, rs2296651) in the solute carrier family 10 member 1 gene (SLC1OA1) completely abolished the HBV receptor function of human NTCP [10]. In addition, a previous study showed that the S267F mutant of NTCP had normal cell surface expression, but resulted in almost complete loss of bile salt uptake [11]. Starting from this known functional polymorphism, some case control association studies on HBV infection were conducted among Asian patients. However, the results were not consistent [12-15].

The aim of this study was to determine whether the SLC10A1 rs2296651 (S267F) polymorphism was associated with resolution or the progression of hepatitis B in patients from Morocco.

\footnotetext{
* Correspondence: sayeh.ezzikouri@pasteur.ma

${ }^{1}$ Virology Unit, Viral Hepatitis Laboratory, Institut Pasteur du Maroc, 1, Place

Louis Pasteur, 20360 Casablanca, Morocco

Full list of author information is available at the end of the article
} 
Table 1 Baseline characteristics of patients

\begin{tabular}{|c|c|c|c|}
\hline & $\begin{array}{l}\text { Chronic HBV infection } \\
(N=286)\end{array}$ & $\begin{array}{l}\text { HBV-Spontaneous } \\
\text { clearance }(N=135)\end{array}$ & $\begin{array}{l}\text { Healthy controls } \\
(N=109)\end{array}$ \\
\hline Median age (range), y & $42(19-78)$ & $52(19-85)$ & $53(25-76)$ \\
\hline \multicolumn{4}{|l|}{ Gender (\%) } \\
\hline Male & 60.14 & 38.51 & 50.46 \\
\hline Female & 39.86 & 61.49 & 49.54 \\
\hline $\begin{array}{l}\text { Mean Alanine aminotransferase } \pm \\
\text { SD (IU/L) }\end{array}$ & $55.66 \pm 25.63$ & $28.36 \pm 6.32$ & $26.80 \pm 5.72$ \\
\hline $\begin{array}{l}\text { Mean Aspartate aminotransferase } \pm \\
\text { SD (IU/L) }\end{array}$ & $48.09 \pm 24.87$ & $25.93 \pm 5.45$ & $21.70 \pm 2.64$ \\
\hline HBeAg positive (\%) & 5.5 & - & - \\
\hline Anti-HBe positive (\%) & 94.5 & - & - \\
\hline Median log10 HBV-DNA (IU/ml) & $4.4(3.8-6.5)$ & - & - \\
\hline \multicolumn{4}{|l|}{ Genotypes (\%) } \\
\hline $\mathrm{D}$ & 89 & - & - \\
\hline A & 11 & - & - \\
\hline \multicolumn{4}{|l|}{ SLC10A1 (rs2296651, G>A) } \\
\hline GG & $286(100 \%)$ & $135(100 \%)$ & $109(100 \%)$ \\
\hline AG & 0 & 0 & 0 \\
\hline AA & 0 & 0 & 0 \\
\hline
\end{tabular}

\section{Methods}

To address this issue, a total of 530 consented Moroccan participants were independently recruited at Institut Pasteur du Maroc. From May 2008 through January 2015, 286 CHB patients (172 males) with a median age of 42 years (range 19-78), 135 (52 males) individuals with spontaneous clearance from HBV infection, who were positive for antibody against hepatitis B core antigen and negative for hepatitis B surface antigen ( $\mathrm{HBsAg}$ ), with a median age of 52 years (range 19-85) and 109 healthy controls (55 males) negative for hepatitis serological markers with a median age of 53 years (range 25-76) were enrolled in the present study. The study was approved by the Ethics Committee of the Faculté de Medicine of Casablanca. The rs2296651 polymorphism was genotyped using a TaqMan SNP Genotyping Assay (Applied Biosystems; assay ID C_16184554_10). Approximately $15 \%$ of total DNA samples were repeated for quality control, and no discrepancy was observed.

\section{Results \& discussion}

We investigated the association between the serine/ phenylalanine polymorphism located at codon 267 of SLC1OA1 and HBV infection status in a case-control study of $286 \mathrm{CHB}$ and 135 subjects with spontaneous clearance from HBV infection. Moreover, to estimate the frequencies of the SLC1OA1 genotypes in the general Moroccan population, the rs2296651 was genotyped in 109 healthy controls. The demographic, biochemical and virological characteristics of the population studied are shown in Table 1. In this cohort, we detected only wild- type genotype (S267S) in all groups and there were no differences between groups. Our finding is in contrast with previous asian studies, and suggest that this polymorphism may be specific to Asian populations. A recent large cohort study showed that heterozygous and homozygous subjects for S267F polymorphism were resistant to $\mathrm{CHB}$ [12]. Moreover, other findings support this association and showed that S267F homozygotes were strongly associated with $\mathrm{HBsAg}$-seronegativity [13]. However, other previous studies showed that the S267F variant was associated with susceptibilty to HBV infection $[14,16]$. Furthermore, a recent report found that the frequency of the mutant allele was decreased in the positive HBsAg group and increased in HBsAg and HBeAg positive groups relative to controls [15].

\section{Conclusions}

Our data showed that S267F is not associated with HBV infection, and is not prevalent in the general Moroccan population.

\section{Abbreviations}

CHB: Chronic hepatitis B; HBV: Hepatitis B virus; NTCP: Sodium taurocholate cotransporting polypeptide; SLC10A1: Solute carrier family 10 member 1

\section{Acknowledgements}

The authors would like to acknowledge all patients for their participation in this study. We are particularly grateful to Prof. George $Y$. Wu for pertinent review and useful English revision of the manuscript.

\section{Funding}

The study was supported by the Association de Lutte Contre le SIDA (ALCS, FASP2012). 


\section{Availability of data and materials}

Raw data cannot be shared due to patient confidentiality and all other information is contained within this article.

\section{Authors' contributions}

Ezzikouri S conceived, designed the experiments and wrote the paper; Chihab $\mathrm{H}$ performed SNP genotyping; Wakrim $\mathrm{L}$ and Elhabazi A analyzed the data and designed the experiments; Benjelloun $\mathrm{S}$ collected samples and clinical data, conceived and designed the experiments. All authors read and approved the final manuscript.

\section{Competing interests}

The authors declare that they have no competing interests.

\section{Consent for publication}

Not applicable.

\section{Ethics approval and consent to participate}

The study was approved by the Ethics Committee of the Faculté de Medicine of Casablanca.

\section{Author details}

'Virology Unit, Viral Hepatitis Laboratory, Institut Pasteur du Maroc, 1, Place Louis Pasteur, 20360 Casablanca, Morocco. ${ }^{2}$ Cell Biology Department, Faculty of Sciences, Chouaib Doukkali University, El-Jadida, Morocco. ${ }^{3}$ Virology Unit, Immunovirology Laboratory, Institut Pasteur du Maroc, Casablanca, Morocco.

\section{Received: 15 July 2016 Accepted: 20 January 2017}

Published online: 26 January 2017

\section{References}

1. Perz JF, Armstrong GL, Farrington LA, Hutin YJ, Bell BP. The contributions of hepatitis $B$ virus and hepatitis $C$ virus infections to cirrhosis and primary liver cancer worldwide. J Hepatol. 2006;45(4):529-38.

2. Schweitzer A, Horn J, Mikolajczyk RT, Krause G, Ott JJ. Estimations of worldwide prevalence of chronic hepatitis B virus infection: a systematic review of data published between 1965 and 2013. Lancet. 2015;386(10003): 1546-55.

3. Rehermann B, Nascimbeni M. Immunology of hepatitis B virus and hepatitis C virus infection. Nat Rev Immunol. 2005:5(3):215-29.

4. Jung MC, Pape GR. Immunology of hepatitis B infection. Lancet Infect Dis. 2002;2(1):43-50.

5. Ezzikouri S, Kitab B, Rebbani K, Marchio A, Wain-Hobson S, Dejean A, Vartanian JP, Pineau P, Benjelloun S. Polymorphic APOBEC3 modulates chronic hepatitis B in Moroccan population. J Viral Hepat. 2013;20(10):678-86.

6. Kamatani Y, Wattanapokayakit S, Ochi H, Kawaguchi T, Takahashi A, Hosono N, Kubo M, Tsunoda T, Kamatani N, Kumada H, Puseenam A, Sura T, Daigo Y, Chayama K, Chantratita W, Nakamura Y, Matsuda K. A genome-wide association study identifies variants in the HLA-DP locus associated with chronic hepatitis B in Asians. Nat Genet. 2009;41(5):591-5.

7. Grunhage F, Nattermann J. Viral hepatitis: human genes that limit infection. Best Pract Res Clin Gastroenterol. 2010;24(5):709-23.

8. Yan $H$, Zhong G, Xu G, He W, Jing Z, Gao Z, Huang Y, Qi Y, Peng B, Wang H, Fu L, Song M, Chen P, Gao W, Ren B, Sun Y, Cai T, Feng X, Sui J, Li W. Sodium taurocholate cotransporting polypeptide is a functional receptor for human hepatitis B and D virus. Elife. 2012;1:e00049.

9. Kullak-Ublick GA, Stieger B, Hagenbuch B, Meier PJ. Hepatic transport of bile salts. Semin Liver Dis. 2000;20(3):273-92.

10. Yan H, Peng B, Liu Y, Xu G, He W, Ren B, Jing Z, Sui J, Li W. Viral entry of hepatitis $B$ and $D$ viruses and bile salts transportation share common molecular determinants on sodium taurocholate cotransporting polypeptide. J Virol. 2014;88(6):3273-84.

11. Ho RH, Leake BF, Roberts RL, Lee W, Kim RB. Ethnicity-dependent polymorphism in $\mathrm{Na}+$-taurocholate cotransporting polypeptide (SLC10A1) reveals a domain critical for bile acid substrate recognition. J Biol Chem. 2004;279(8):7213-22.

12. Peng L, Zhao Q, Li Q, Li M, Li C, Xu T, Jing X, Zhu X, Wang Y, Li F, Liu R, Zhong C, Pan Q, Zeng B, Liao Q, Hu B, Hu ZX, Huang YS, Sham P, Liu J, Xu S, Wang J, Gao ZL, Wang Y. The p.Ser267Phe variant in SLC10A1 is associated with resistance to chronic hepatitis B. Hepatology. 2015;61(4):1251-60.
13. Hu HH, Liu J, Lin YL, Luo WS, Chu YJ, Chang CL, Jen CL, Lee MH, Lu SN, Wang LY, You SL, Yang HI, Chen CJ, Group R-HS. The rs2296651 (S267F) variant on NTCP (SLC10A1) is inversely associated with chronic hepatitis B and progression to cirrhosis and hepatocellular carcinoma in patients with chronic hepatitis B. Gut. 2016;65(9):1514-21.

14. Li N, Zhang P, Yang C, Zhu Q, Li Z, Li F, Han Q, Wang Y, Lv Y, Wei P, Liu Z. Association of genetic variation of sodium taurocholate cotransporting polypeptide with chronic hepatitis B virus infection. Genet Test Mol Biomarkers. 2014;18(6):425-9.

15. Yang J, Yang Y, Xia M, Wang L, Zhou W, Yang Y, Jiang Y, Wang H, Qian J, Jin L, Wang $X$. A genetic variant of the NTCP gene is associated with HBV infection status in a Chinese population. BMC Cancer. 2016;16(1):211.

16. Su Z, Li Y, Liao Y, Cai B, Chen J, Zhang J, Li L, Ying B, Tao C, Zhao M, Ba Z, Zhang Z, Wang L. Polymorphisms in sodium taurocholate cotransporting polypeptide are not associated with hepatitis B virus clearance in Chinese Tibetans and Uygurs. Infect Genet Evol. 2016;41:128-34.

\section{Submit your next manuscript to BioMed Central and we will help you at every step:}

- We accept pre-submission inquiries

- Our selector tool helps you to find the most relevant journal

- We provide round the clock customer support

- Convenient online submission

- Thorough peer review

- Inclusion in PubMed and all major indexing services

- Maximum visibility for your research

Submit your manuscript at www.biomedcentral.com/submit
) Biomed Central 